\title{
Congenital Perceptive Deafness: Role of Intrauterine Rubella
}

\author{
SHIRLEY M. GUMPEL， KATHLEEN HAYES， J. A. DUDGEON
}

British Medical fournal, 1971, 2, 300-304

\begin{abstract}
Summary
Rubella antibody was detected in $85(61 \%)$ of 139 children aged from 6 months to 7 years with congenital perceptive deafness. Of the 112 children who were aged under 4 years $61(54 \%)$ had rubella antibody (seropositive) compared with $7 \cdot 1 \%$ in randomly selected children of the same age. A close correlation was found between the presence of antibody in children with perceptive deafness and (1) a maternal history of rash or contact in early pregnancy, and (2) with the presence of other rubella-type defects. Intrauterine rubella was thought to be the cause of the deafness in $82(59 \%)$ of the 139 children, in 60 of whom deafness was the only rubella defect detected. Thus intrauterine rubella should be considered a likely cause of congenital perceptive deafness in a child under 4 years in whom rubella antibody is present.
\end{abstract}

\section{Introduction}

Congenital perceptive or sensorineural deafness is one of the most frequent manifestations of intrauterine rubella. Fisch (1969) estimated that the incidence of deafness from rubella may vary from $6 \%$ after a non-epidemic year to $33 \%$ after an epidemic year, and that there may be $20-30 \%$ of children in whom no cause for the deafness can be found. Similar figures for children with severe preceptive deafness without obvious cause have been reported by Barton et al. (1962).

The problem is further complicated by the fact that on subsequent reassessment of a group of children the incidence and severity of hearing loss have been found to be increased. In a survey in 1951-2 of the effect of rubella and other virus infections in pregnancy Manson et al. (1960) recorded that $6 \%$ of 37 malformed children were deaf $(2.7 \%$ actual, $3.3 \%$ suspected), but subsequent studies on small numbers of the same children at 2, 5, and 8 to 11 years showed that $12-19 \%$ had a significant hearing defect (Jackson and Fisch, 1958; Manson et al., 1960; Sheridan, 1964). Similarly, Barr and Lundström (1961) found that the incidence of hearing loss increased later in childhood.

These figures were based on a clinical diagnosis of maternal rubella. The discovery that intrauterine rubella led to a chronic infection with persistence of antibody for prolonged periods after birth made retrospective diagnosis of intrauterine rubella infection possible (Plotkin et al., 1963; Dudgeon et al., 1964; Weller et al., 1964). Butler et al. (1965) found an unexpectedly high incidence of rubella antibody in a group of 70 children aged 1-3 years who had been exposed to maternal rubella in the first 20 weeks of pregnancy. Antibody was

Department of Microbiology, the Hospital for Sick Children, Great Ormond Street, London WCIN $3 J H$

SHIRLEY M. GUMPEL, M.B., B.S., Research Fellow

KATHLEEN HAYES, M.B., D.c.H., Research Fellow (Present address: Roval Children's Hospital, Melbourne, Victoria, Australia)

J. A. DUDGEON, M.D., F.R.C.PATH., Consultant present in 18 out of 20 children who were either deaf or who had pigmentary retinopathy and in 21 out of 48 who had been exposed to maternal rubella but who had no observable defects, compared with $5.6 \%$ in a random control group. More recently Karmody (1968) showed that 23 out of 28 congenitally deaf children in Trinidad had rubella antibody, compared with 9 out of 30 control children.

When more than one of the commonly encountered defects of congenital rubella are present the diagnosis is seldom in doubt, but hearing defects may occur as the only manifestation and with no history of maternal infection. In this situation serological tests may be of diagnostic value. The purpose of this retrospective study was to assess the role of serological tests for rubella antibody in identifying intrauterine rubella as the cause of a congenital perceptive deafness.

\section{Patients and Methods}

\section{STUDY POPULATION}

Between August 1966 and April 1968150 children with congenital deafness attending the Nuffield Hearing and Speech Centre, Gray's Inn Road, London; and their mothers were investigated for the presence of rubella antibody. The children's ages ranged from 6 months to 7 years, most being under 4 years. Initially there was a bias towards studying children whose mothers had had rubella during pregnancy, but after January 1967 all children with congenital perceptive or sensorineural deafness were included. So far as possible children suffering from acquired or conductive deafness as a result of infection in early infancy were excluded.

Clinical Data.-Details of the pregnancy, delivery, birth weight, and subsequent development of each child were obtained and when possible tests for hearing were recorded audiometrically by the staff of the centre. Additional information was provided by evoked-response audiometry in the children with multiple handicaps, particularly when vision was affected by bilateral cataracts.

Psychological Examination.-Psychological evaluation of most children was made by means of the Merrill-Palmer and Griffith scales. The intelligence of children who could not be given formal testing was estimated by a psychologist.

\section{LABORATORY STUDIES}

Serology.-Blood from the mothers and the children was tested in the virus laboratory at the Hospital for. Sick Children, Great Ormond Street. Rubella antibody was measured at first by the virus neutralization test (Dudgeon et al., 1964), and later by the haemagglutination-inhibition test (Stewart et al., 1967) with minor modifications of our own. Since a good correlation exists between the two tests the results from both have been combined. Sera with rubella antibody titre of 1 in 4 or greater were regarded as positive (seropositive); those with less than 1 in 4 were regarded as negative (seronegative).

Virus Isolation.-Nose and throat swabs for rubella virus isolation were taken only from children who were under 2 years of age. The specimens were inoculated into RK13 cells 
according to the methods previously described from this laboratory (Dudgeon et al., 1964).

\section{CONTROL STUDY GROUP}

The significance of rubella antibody in a child with a congenital defect such as cataracts, heart disease, deafness, or retinopathy depends on the probability that the antibody is the result of intrauterine rather than postnatal infection. Therefore in perceptive deafness it is important to compare the incidence of rubella antibody in deaf children with that in normal children matched for age and sex. Such data are difficult to obtain for ethical reasons, and we had to rely on whatever control material was available from children undergoing routine investigations at the hospital. Rubella haemagglutination-inhibition antibody tests were made on 269 randomly selected children aged 6 months to 7 years attending the outpatient department. Approximately equal numbers in each year's age group were available for study.

\section{Results}

One hundred and fifty children aged 6 months to 7 years with congenital perceptive deafness were investigated, but since serum samples were unobtainable from 11 mothers only 139 cases have been included in this report.

\section{SEROLOGICAL RESULTS}

Of the 139 children examined $85(61 \%)$ were found to have rubella antibody (seropositive) and $54(39 \%)$ had no detectable antibody (seronegative). A history of maternal rubella rash or contact was obtained in 64 of the 85 seropositive cases. The mothers of these children were also seropositive. In contrast, in the seronegative group of 54 children there were no cases with a history of maternal rubella with a rash. A history of contact was obtained in only four cases, and in 50 there was no history of either rash or contact during pregnancy. Three of the mothers of these children were seronegative. The results of the laboratory findings are shown in Table 1 .

Age.-Of the 139 children examined 112 were aged under 4 (range $6 / 12$ to $47 / 12$ ) and $61(54 \%$ ) of these were seropositive compared with $7 \cdot 1 \%$ in the control group of the same age. The difference is statistically significant. The difference in the incidence of rubella antibody in the remaining 27 children aged 4 to 7 years was not statistically different from the control group. Of 32 children seen during the first 6 months of the study, when there was some selection of cases on the basis of the maternal history, there was a maternal history of rubella in 20 cases and no history of maternal rash or contact in 12. In the ensuing 107 unselected cases a history of maternal rubella was obtained in 48 and in 59 there was no history of rash or contact-so the bias in early selection made little difference.

Relation between Rubella Antibody Titre, Maternal History, and Defect.-The same range in virus-neutralization and haemagglutination-inhibition antibody titre was found in children with deafness alone, irrespective of their age. A slightly higher geometric mean titre was found in those with multiple defects, but it was statistically insignificant, as was the difference in the geometric mean titre between children with multiple defects and with a history of maternal rubella and those with defects and with no history. The general pattern of antibody response was similar to that in the main series of congenital rubella patients reported from this hospital (Dudgeon et al., 1969).

\section{VIRUS ISOLATION}

Rubella virus was not isolated from any of the 24 children under 2 years of age.

\section{AETIOLOGICAL GROUPS}

On the basis of this evidence and in order to compare the clinical data in more details it was decided to divide the cases into a "rubella" and a "non-rubella" group, on the ground that the deafness in the first group was more likely to be rubella in origin than that in the second. In apportioning the cases the following factors were taken into account: (1) a history of maternal rubclla with a rash or of contact with rubella in the first 20 weeks of pregnancy, (2) the presence of other defects of the rubella type, and (3) the presence of antibody alone in a deaf child under the age of 4 years.

In 64 of the 85 seropositive patients a maternal history or the presence of other defects made it reasonable to suppose that congenital rubella was the cause of the deafness, and it was also reasonable to suspect rubella as the cause in 18 of the 21 seropositive children in whom there was no maternal history of rubella or of contact. Ten of these under 4 years of age had deafness alone and eight aged 6 months to 7 years had other rubella type defects. Three seropositive children aged 4 to 7 years with deafness alone were transferred to the non-rubella group because their antibody might have resulted from postnatal injection. Thus in 82 of these seropositive children the congenital perceptive deafness was thought to be

TABlE I-Findings in 139 Children with Congenital Perceptive Deafness. Relation between Maternal History, Defect, Age, and Serological Status

\begin{tabular}{|c|c|c|c|c|c|c|c|c|c|c|c|c|}
\hline \multirow{3}{*}{\multicolumn{2}{|c|}{$\begin{array}{l}\text { Age and } \\
\text { Serological } \\
\text { Status }\end{array}$}} & & \multicolumn{9}{|c|}{ History of Maternal Illness } & \multirow{3}{*}{ Total } \\
\hline & & & \multicolumn{3}{|c|}{ Maternal Rubella Rash } & \multicolumn{3}{|c|}{ Contact with Rubella } & \multicolumn{3}{|c|}{ No History } & \\
\hline & & & $\begin{array}{l}\text { Deafness } \\
\text { Alone }\end{array}$ & $\begin{array}{c}\text { Deafness }+ \\
\text { Other Rubella } \\
\text { Defects }\end{array}$ & Total & $\begin{array}{l}\text { Deafness } \\
\text { Alone }\end{array}$ & $\begin{array}{l}\text { Deafness }+ \\
\text { Other Rubella } \\
\text { Defects }\end{array}$ & Total & $\begin{array}{l}\text { Deafness } \\
\text { Alone }\end{array}$ & $\begin{array}{c}\text { Deafness }+ \\
\text { Other Rubella } \\
\text { Defects }\end{array}$ & Total & \\
\hline $\begin{array}{l}\text { Seropositive: } \\
6 / 12 \text { to } 47 / 12 \\
4 \text { to } 7 \text { years }\end{array}$ & $\begin{array}{l} \\
\ldots \\
\cdots\end{array}$ & $\because$ & $\begin{array}{r}38 \\
7\end{array}$ & $\begin{array}{l}5 \\
6\end{array}$ & $\begin{array}{l}43 \\
13\end{array}$ & $\begin{array}{l}4 \\
1\end{array}$ & $\begin{array}{l}1 \\
2\end{array}$ & $\begin{array}{l}5 \\
3\end{array}$ & 10 & $\begin{array}{l}3 \\
5\end{array}$ & $\begin{array}{r}13 \\
8\end{array}$ & $\begin{array}{l}\mathbf{6 1} \\
24\end{array}$ \\
\hline Total & . & . & 45 & 11 & 56 & 5 & 3 & 8 & 13 & 8 & 21 & 85 \\
\hline $\begin{array}{l}\text { Seronegative: } \\
6 / 12 \text { to } 47 / 12 \\
4 \text { to } 7 \text { years }\end{array}$ & $\begin{array}{l}\cdots \\
\cdots\end{array}$ & $\begin{array}{l}. \\
\therefore\end{array}$ & $\begin{array}{l}0 \\
0\end{array}$ & $\begin{array}{l}0 \\
0\end{array}$ & $\begin{array}{l}0 \\
0\end{array}$ & $\begin{array}{l}4^{*} \\
0\end{array}$ & $\begin{array}{l}0 \\
0\end{array}$ & $\begin{array}{l}4 \\
0\end{array}$ & $\frac{47(3 \dagger)}{3}$ & $\begin{array}{l}\mathbf{0} \\
\mathbf{0}\end{array}$ & $\begin{array}{r}47 \\
3\end{array}$ & $\begin{array}{r}51 \\
3\end{array}$ \\
\hline Total & . & $\cdots$ & 0 & 0 & 0 & 4 & 0 & 4 & 50 & 0 & 50 & 54 \\
\hline Grand Total & & $\ldots$ & 45 & 11 & 56 & 9 & 3 & 12 & 63 & 8 & 71 & 139 \\
\hline
\end{tabular}

* Placed in non-rubella group (see text).

+ Three with other defects of the non-rubella type. 
attributable to intrauterine rubella. The non-rubella group comprised the 54 seronegative children and the three older seropositive deaf children. Details of the two groups are set out in Table II.

TABLE II-Congenital Perceptive Deafness. Number of Cas's considered to be Due to Intrauterine Rubella and to other Causes.

Rubella Group (Seropositive)

6 months to 7 years, following maternal rubella with rash and including other rubella defects 6 months to 7 years, following maternal rubella contact and including

6 months to 7 years, no history but other rubella defects $\quad \ldots \quad \ldots$

Non-rubella Group (Mainly Seronegative) 6 months to 7 years, no history, no defects (seronegative) following maternal contact (seronegative) 4 to 7 years, no history, no other defects (seropositive) other rubella defects

6 month to 3 years, no history

No. of
Cases

\section{DEFECTS AND STAGE OF MATERNAL INFECTION}

Details of the maternal illness (see Table III) were available in 64 cases; the children were all seropositive. Deafness as a single defect occurred as a result of maternal rubella as early as in the first month and as late as in the fifth month of pregnancy, whereas cases with other rubella defects were associated with maternal infection in the first trimester.

\section{DETAILS OF HEARING DEFECTS}

All but one of the 139 children had bilateral hearing loss, though in some cases one ear was only slightly affected.

Rubella Group.-In 60 of the 82 children deafness was the only defect detected. Audiograms in 34 of these children showed severe bilateral hearing loss in 23 and the loss for the less affected ear was 40 decibels over the speech frequencies of 500-40,000 cycles/sec. Many of the audiograms from the rubella group showed hearing loss over all frequencies, but in 11 there was a maximum loss in the middle frequencies, which produced a trough.

Non-rubella Group.-In 54 of the 57 cases deafness was the only defect detected. Audiograms were more varied and showed a less constant pattern, though some showed maximum loss in the middle frequencies. In general there was no clear difference in audiometric pattern between the two groups when deafness was the only defect.

\section{OTHER DEFECTS OF RUBELLA AND NON-RUBELLA TYPES}

Altogether 25 patients were observed with other defects, 22 being of the type usually associated with congenital rubella. The details are shown in Tables IV and V.

Rubella Group.-The 22 children with rubella type additional defects were all seropositive. Most of these children had multiple handicaps (see Table IV). In 13 of these 22 cases there was a history of maternal rubella in the first trimester.

Non-rubella Group.-Three children were observed with other congenital defects, all of whom were seronegative (see Table V). Two had a harelip and cleft palate, one of whom also had a nasal dermoid and was mentally retarded. The third child was mentally retarded as well as deaf. Other possible aetiological factors were found in seven other seronegative children with deafness alone. One mother had had severe antepartum haemorrhage; in two children there was a family history of deafness, with siblings affected; and four mothers gave a history of an "influenza-like" illness during the third month of pregnancy.

\section{PSYCHOLOGICAL EVALUATION}

Records of psychological assessments using the MerrillPalmer and Griffith scales were made on 57 children.

Rubella Group.-Sixteen of 43 children examined were mentally retarded by one or more standard deviations from the mean. Many of the children were unable to complete the tests owing to general immaturity or lack of concentration and in five cases because of other abnormalities.

Non-rubella Group.-Five of 29 children examined were found to have severe mental retardation. The results are based only on performance scores. Language input and output were not included as they would have made the general figure of ability meaningless. In all cases understanding of the spoken word and output were markedly reduced.

\section{BIRTH WEIGHTS}

The birth weights of the children with rubella deafness as the only defect were similar to those of the non-rubella deaf children but were statistically higher than the weights of the deaf children with multiple rubella defects (Table VI).

TABLE III-Relation between Congenital Defects and Week of Pregnancy when Exposed to Maternal Rubella in the 82 Cases of Congenital Perceptive Deafness in the Rubella Group

\begin{tabular}{|c|c|c|c|c|c|c|c|c|}
\hline \multirow[b]{2}{*}{ Week of Pregnancy } & \multicolumn{7}{|c|}{ Rubella Rash or Contact in Month of Pregnancy } & \multirow{2}{*}{$\begin{array}{l}\text { Incidence of Specified } \\
\text { Defect in Relation to } \\
\text { Number Examined }\end{array}$} \\
\hline & $1-4$ & $5-8$ & $9-12$ & $13-16$ & $17-20$ & \begin{tabular}{|c|}
$\begin{array}{c}\text { Early Pregnancy } \\
\text { (exact dates } \\
\text { not known) }\end{array}$ \\
\end{tabular} & Total & \\
\hline $\begin{array}{lll}\text { Rash/contact } & . . & . .\end{array}$ & $8 / 1$ & $27 / 1$ & $13 / 1$ & $5 / 1$ & $1 / 0$ & $2 / 4$ & 64 & \\
\hline Deafness as single defect & 6 & 24 & 16 & 6 & 1 & 7 & 60 & $60 / 82(73 \%)$ \\
\hline 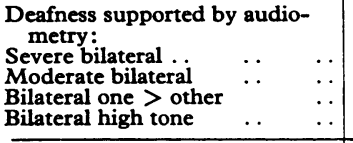 & $\begin{array}{r}3 \\
1 \\
1 \\
-\end{array}$ & $\begin{array}{r}6 \\
2 \\
1 \\
-\end{array}$ & $\begin{array}{l}6 \\
1 \\
1 \\
-\end{array}$ & $\frac{3}{-}$ & 二 & $\begin{array}{l}5 \\
\frac{3}{1} \\
\end{array}$ & $\left.\begin{array}{r}23 \\
7 \\
3 \\
1\end{array}\right\} 34$ & \\
\hline $\begin{array}{lllll}\text { Cataract } & . & \ldots & \ldots & \ldots \\
\text { Squint } & . & \ldots & \ldots & \ldots \\
\text { Other } & . . & \ldots & \ldots & . \\
\end{array}$ & $\begin{array}{r}3 \\
1 \\
-\end{array}$ & $\underline{3}$ & $\begin{array}{l}1 \\
1 \\
\end{array}$ & 二 & $=$ & $\begin{array}{l}3 \\
1 \\
1 \\
\end{array}$ & $\left.\begin{array}{r}10 \\
3 \\
1\end{array}\right\} 14$ & $14 / 82(17 \%)$ \\
\hline Congenital Heart Disease & 2 & - & - & - & - & 3 & 5 & $5 / 82 \quad(6 \%)$ \\
\hline $\begin{array}{l}\text { Mental Retardation: } \\
-1 \text { S.D. to }{ }^{-2} \text { S.D. (70-85 IQ) } \\
\text {-2S.D. to }{ }^{-3} \text { S.D. (55-70 IQ) } \\
\text {-2S.D. to }{ }^{-4} \text { S.D. ( }(30-55 \text { IQ }) \\
\end{array}$ & $\underline{-}$ & $\begin{array}{l}4 \\
1 \\
1 \\
\end{array}$ & $\underline{-}$ & $=$ & 二 & $\begin{array}{r}3 \\
3 \\
-\end{array}$ & $\left.\begin{array}{l}8 \\
7 \\
1\end{array}\right\} 16$ & $16 / 43(37 \%)$ \\
\hline Birth weight below $5 \frac{1}{2} \mathrm{lb}(2.5 \mathrm{~kg})$ & - & 4 & 1 & - & - & 7 & 12 & $12 / 59(20 \%)$ \\
\hline Musculoskeletal defects: & 一 & 2 & - & - & - & - & 2 & $2 / 82 \quad(2 \%)$ \\
\hline
\end{tabular}




\section{Discussion}

Two main questions that arise from this study are, firstly, do serological tests help in differentiating perceptive deafness due to intrauterine rubella from deafness due to other causes; and, secondly, can deafness due to rubella be recognized on clinical grounds alone?

That intrauterine rubella causes a production of antibody which persists for prolonged periods after birth has been repeatedly confirmed (Dudgeon et al., 1964; Weller et al., 1964; Cooper and Krugman, 1967). A retrospective diagnosis of intrauterine infection is best made in the first few years of life after maternally transmitted antibody has disappeared and before antibody is acquired from exposure to the natural disease. In practice, this usually means between the ages of 6 months and 3 to 4 years. Lundström et al (1967) found no antibody in normal 2-year-old children but it was present in $14 \%$ of children aged 5 . Our more recent findings in randomly selected control children under 4 years showed antibody present in $7 \cdot 1 \%$ compared with $5.6 \%$ in a previous control series (Butler et al., 1965). In the case of congenital rubella antibody is present in almost $100 \%$ of children of that age group. But, except in the first few months of life when levels of immunoglobulin $M$ in congenital rubella are often markedly raised, there is no certain way of distinguishing between fetal and postnatally acquired antibody. Therefore, unless serial serum samples are available, serological tests by themselves can point only to a probability that the infection was acquired in utero.

Of the 139 children aged 6 months to 7 years in this series $85(61 \%)$ were seropositive. It is of greater significance that $61(54 \%)$ of the 112 under the age of 4 were seropositive. This is statistically higher than the figure of $7.1 \%$ in the control series. There are several reasons for believing that our conclusion that perceptive deafness in 82 of the 139 children was attributable to intrauterine rubella is valid. Firstly, in 64 out of 68 cases there is a close correlation between a history of maternal rubella or of contact and the presence of antibody in the child. Secondly, the correlation between the presence of antibody and the presence of other defects of the rubella type is even closer (22 out of 22). The most important cases, however, are the 71 children in whom there was no maternal history of rash or contact. If intrauterine rubella were the cause of deafness in the 18 seropositive children out of these 71 it would represent $25 \%$ of a group which would otherwise be classified as of "unknown aetiology."

TABLE IV-Details of other Congenital Abnormalities in 22 Children in the Rubella Group

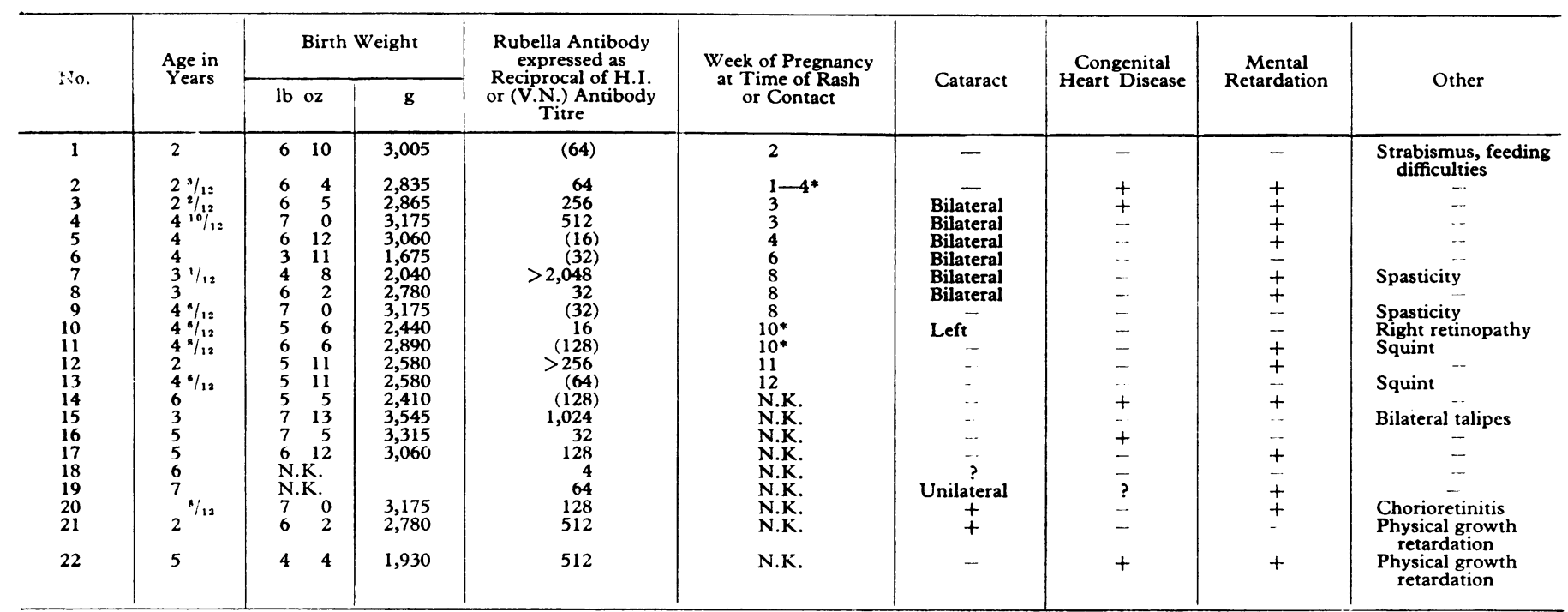

H.I. = Haemagglutination-inhibition. $($ V.N. $)=$ Virus neutralizing antibody. These numbers are in parentheses.
Contact.

TABLE V-Details of Other Congenital Abnormalities in the Non-rubella Group

\begin{tabular}{|c|c|c|c|c|c|c|c|c|c|}
\hline \multirow{2}{*}{ No. } & \multirow{2}{*}{$\begin{array}{l}\text { Age in } \\
\text { Years }\end{array}$} & \multicolumn{3}{|c|}{ Birth Weight } & \multirow{2}{*}{$\begin{array}{c}\text { Rubella Antibody } \\
\text { Expressed as } \\
\text { Reciprocal of H.I. } \\
\text { Antibody Titre or } \\
\text { (V.N.) }\end{array}$} & \multirow{2}{*}{ Cataract } & \multirow{2}{*}{$\begin{array}{c}\text { Congenital } \\
\text { Heart Disease }\end{array}$} & \multirow{2}{*}{$\begin{array}{c}\text { Mental } \\
\text { Retardation }\end{array}$} & \multirow{2}{*}{ jther } \\
\hline & & $\mathrm{lb}$ & oz & g & & & & & \\
\hline $\begin{array}{l}23 \\
24 \\
25\end{array}$ & $\begin{array}{l}21 \\
32 \\
21\end{array}$ & & $\begin{array}{l}9 \\
8 \\
0\end{array}$ & $\begin{array}{l}2,525 \\
3,400 \\
2,720\end{array}$ & $\begin{array}{l}\text { <4 neg. } \\
<4 \text { neg. } \\
<4 \text { neg. }\end{array}$ & $\begin{array}{l}- \\
-\end{array}$ & $\begin{array}{l}\overline{-} \\
\overline{-}\end{array}$ & $\overline{+}$ & $\begin{array}{l}\text { Harelip and clcft palate. Dermoid on nose } \\
\text { Harelip and cleft palate }\end{array}$ \\
\hline
\end{tabular}

TABLE VI-Comparison of Birth Weights of Rubella and Non-rubella Groups

\begin{tabular}{|c|c|c|c|c|}
\hline \multirow{2}{*}{\multicolumn{2}{|c|}{ Detail }} & \multicolumn{2}{|c|}{ Rubella Group } & \multirow{2}{*}{ Non-rubella Deaf } \\
\hline & & Rubella Deaf without Other Defects & Rubella Deaf with Other Defects & \\
\hline $\begin{array}{l}\text { No. of cases .. } \\
\text { Mean weight } \\
\text { Range.. .. } \\
\text { Standard deviation }\end{array}$ & $\begin{array}{ll}\cdots & \cdots \\
\cdots & \cdots \\
\ldots & \\
\ldots & \end{array}$ & $\begin{array}{c}41 \\
7 \mathrm{lb} 0 \mathrm{oz}(3,175 \mathrm{~g}) \\
4 \mathrm{lb} 0 \mathrm{oz}-10 \mathrm{lb} 3 \mathrm{oz} \\
(1,815-4,620 \mathrm{~g}) \\
11 \mathrm{~b} 6 \mathrm{oz}(624 \mathrm{~g})\end{array}$ & $\begin{array}{c}20 \\
6 \mathrm{lb} 2 \mathrm{oz}(2,780 \mathrm{~g}) \\
3 \mathrm{lb} 11 \mathrm{oz}-7 \mathrm{lb} 13 \mathrm{oz} \\
(1,675-3,545 \mathrm{~g}) \\
1 \mathrm{lb} 1 \mathrm{oz}(482 \mathrm{~g})\end{array}$ & $\begin{array}{c}36 \\
7 \mathrm{lb} 4 \mathrm{oz}(3,290 \mathrm{~g}) \\
5 \mathrm{lb} 9 \mathrm{oz}-8 \mathrm{lb} 12 \mathrm{oz} \\
(2,525-3,970 \mathrm{~g}) \\
13 \mathrm{oz}(370 \mathrm{~g})\end{array}$ \\
\hline
\end{tabular}

The difference between the rubella-deaf cases with other defects and the non-rubella cases is statistically significant $\left(t_{50}=4.66 ; P<0.001\right)$ as is the difference between the

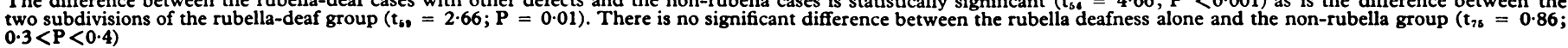


It could also be argued that some of the 54 seronegative cases were also caused by intrauterine rubella but had lost antibody. If true, this would add to the number of cases of congenital perceptive deafness caused by intrauterine rubella. Recent investigations indicate that the view that antibody in congenital rubella patients will persist for a prolonged period, if not indefinitely (Dudgeon, 1967), may require qualification. In a recent review of 50 of the late Sir Norman Gregg's original cases of congenital rubella seen at 25 years of age Kenrick et al. (1968) found that six patients had no detectable haemagglutination-inhibition antibody, seven had very low titres, and two had very high titres. Hardy et al. (1969) also reported loss of antibody in about $10 \%$ of their cases of congenital rubella. Our experience in a serial study of children aged 1-7 years with congenital rubella was that only one patient out of 98 lost antibody, and in another series of 284 cases from whom single specimens were available it was impossible to say whether the presence of antibody was due to persistence or resulted from reinfection.

Congenital perceptive deafness due to rubella probably cannot be recognized on purely clinical grounds unless some additional marker such as those outlined is present. The same applies to cases of perceptive deafness of genetic origin, in which a family history or the presence of other defects encountered in syndromes found in genetic deafness are equally important in pointing to the aetiology. Like other studies, this survey has shown the importance of the maternal history and the presence of other features in detecting cases due to intrauterine rubella. It has also shown that the birth weight of children with deafness alone may not be significantly lower than that of normal unaffected children, and so this marker is of less value. Unfortunately it was impossible to examine the fundus for pigmentary retinopathy in our cases. Clearly this would be desirable in future studies.

As a general rule multiple defects are more common than single defects in congenital rubella, though they may not be apparent at first. The deafness in congenital rubella is of the perceptive or sensorineural type, but no longer do we think in ierms of damage restricted to the organ of Corti. Damage seems to be more widespread, giving rise to a type of deafness ranging from severe hearing loss to a language disorder. In the present series all but one of the 139 children had bilateral hearing loss, and deafness was the sole defect in 60 of the 82 children with deafness considered to be rubella in origin. Neither of these two features is truly typical of congenital rubella deafness. The difference was no doubt due to the nature of the study sample, since patients with unilateral deafness do not usually present as deaf and are therefore unlikely to attend a centre for hearing and speech defects.

In the children examined more of the rubella than of the nonrubella groups were in the slower-than-normal IQ range, but the differences were not clear cut. The incidence of mental retardation may be greater than recorded because firstly, most children in this group were aged 4 years or under; secondly, both the Merrill-Palmer and Griffiths scales easily overscore; and, thirdly, the results are based on performance scores only.

If our conclusion that most if not all of the 82 cases of congenital perceptive deafness were due to rubella is right it strengthens the belief that intrauterine rubella is the cause of many cases of perceptive deafness of unknown aetiology. This may explain the high incidence $(25 \%)$ of cases in this category which were observed by J. A. M. Martin (personal communication 1969) at the Nuffield Hearing and Speech Centre before these laboratory tests were carried out.

Recognition of the cause of deafness is important because, firstly, parents can be reassured that rubella deafness is unlikely to occur in subsequent siblings; secondly, these children need close follow-up as hearing may deteriorate over a period of years; and finally, and of great practical importance, congenital rubella deafness should in the future be preventable by vaccination.

We thank Mr. J. A. M. Martin, Director of the Nuffield Hearing and Speech Centre, Royal National Throat, Nose and Ear Hospital, Gray's Inn, for his constant help, interest, and advice, and also the members of the staff who referred patients to us: Mr. A. F Walker, Mr. H. A. Beagley, Miss M. Bickerton, and Dr. S. Bolton. We also thank Mrs. M. Wren and Mr. Ian Proctor for their psychological evaluation of the patients. We thank Dr. William C. Marshall for his advice and comments and the technical staff of the Hospital for Sick Children for their skill with the laborotory investigation.

Finally, we express our gratitude to the Medical Research Council for its support of this study (Dr. Kathleen Hayes and Dr. Shirley M. Gumpel).

\section{References}

Barr, B., and Lundström, R. (1901). Acta ()to-laryngologica, 53, 413. Barton, M. E., Court, S. D., and Walker, W. (1962). British Medical fournal, 1, 351

Butler, N. R., Dudgeon, J. A., Hayes, K., Peckham, C. S., Wybar, K. (1965). British Medical fournal, 2, 1027

Cooper, L. Z., and Krugman, S. (1967). Archives of Ophthalmology, 77, 434.

Dudgeon, J. A. (1967). Archives of Diseases in Childhood, 42, 110

Dudgeon, J. A., Butler, N. R., and Plotkin, S. A. (1964). British Medical

Dudgeon, J. A., Marshall, W. C., and Soothill, J. F. (1969). Fournal of Pediatrics, 75, 1149 .

Fisch, L. (1969). Public Health, 83, 68.

Hardy, Janet B., McCracken, G. H., Gilkeson, M. R., and Sever, J. L. (1969). Fournal of the American Medical Association, 207, 2414

Jackson, A. D. M., and Fisch, L. (1968). Lancet, 2, 1241.

Karmody, C. S. (1968). Nezv England fournal of Medicine, 278, 809 Kenrick, K. G., Slinn, R. F., Dorman, D. C., and Menser, M. A. (1968). Lancet, 1, 548 .

Lundström, R., Svedmyr, A., Hagbard, L., and Kaijser, K. (1967). Acta Paediatrica Scandinavica, 56, 279.

Manson, Margaret M., Logan, W. P. D., and Loy, R. M. (1960). Reports on Public Health and Medical Subjects, No 101 I ondon Plotkin, S. A., Dudgeon, J. A., and Ramsay, A. M. (1963). British Medical foumal, 2, 1296.

Shcridan, Mary D. (1964). British Medical Journal, 2. 536.

Stewart, G. L., et al. (1967). New England Fournal of Medicine, 276, 554

Weller, T. H., Alford, C. A., and Neva, F. A. (1964). New England fournal of Medicine, 270, 1039. 